\title{
QUANTITATIVE ESTIMATION OF MORDENITE AND CLINOPTILOLITE IN SEDIMENTARY ROCKS (I)*
}

\author{
Kazuo ToriI, Masami Hotta and Makoto Asaka
}

Government Industrial Research Institute, Tohoku, Sendai 983, Japan

\begin{abstract}
The mineral composition of sedimentary mordenite-clinoptilolite rocks was successfully analyzed by $\mathrm{X}$-ray diffraction division method without the use of internal standards, heating or chemical treatments. This division method utilizes three separate X-ray diffraction methods. Content values of mordenite, clinoptilolite, $\alpha$-quartz, $a$-cristobalite, feldspar and mica were obtained by the standard binary mixtures method. Montmorillonite content was estimated by compairing the $\mathrm{X}$-ray reflection intensities of specimens with that of a standard mineral using (060) plane. The content of amorphous material was analyzed by the two point background intensity method. The mineral compositions of 32 representative zeolite-rock specimens from Japan, U.S.A., New Zealand, Korea and South Africa were determined and are tabulated in Table No. 7.
\end{abstract}

\section{INTRODUGTION}

In recent years, the utilization of natural zeolites altered from volcanic glass has attracted much attention (Mumpton, 1978). In Japan, clinoptilolite-tuff and mordenite-tuff are both abundant and have been used in many phases of agricultural and industrial technology (Torii, 1978).

Although investigations on the nature and properties of these zeolite-tuffs necessarily involve quantitative estimation of their mineralogical composition, unfortunately a reliable method has not previously been reported.

Various criteria such as cation exchange, gas adsorption, X-ray diffraction, chemical analysis (Nakajima and Tanaka, 1967), have been used in an attempt to determine zeolite content in the sedimentary rocks. However each method has limitations and as a result, accurate values of zeolite content have not been obtained by such methods.
In the case of gas adsorption method (Torii et al., 1975) and cation exchange capacity (C.E.C.) method (Negishi, 1972), if zeolite-tuffs contain only one kind of zeolite and furthermore the same appropriate zeolite is used as a standard, extremely good results are obtained. However, when both mordenite and clinoptilolite zeoltes are combined in the same sample, it is very difficult to discriminate between mordenite and clinoptilolite by the above two mentioned methods.

The quantitative values of mordenite in tuffs, which consist of mordenite, $\alpha$-quartz and feldspar, were presumed by Negishi (1972) from the data of X-ray reflection intensity using standard binary mixtures. However, the mordenite content values obtained were relatively higher than the actual values, because the content of amorphous material was not detected. Moreover estimation of clinoptilolite content

- Studies on Utilization of Zeolite Tuff. X. (Manuscript received January 13, 1979) 
by the X-ray diffraction method so far remains unreproted due to the difficulty of getting a pure standard clinoptilolite in Japan.

The authors have succeeded in analysing the mineral composition of sedimentary zeolite rocks by the $\mathrm{X}$-ray diffraction method without the use of any internal standards, heating or chemical treatments. The seven most common minerals analyzed were mordenite, clinoptilolite, $\alpha$-quartz, $a$-cristobalite, feldspar, mica and montmorillonite. The content of amorphous material was also measured by X-ray background method.

\section{EXPERIMENTAL}

\section{Reference standard samples}

Chemical analyses of principal standard samples are presented in Table 1 . Table 2 indicates the mineral composition of the standard zeolite specimens and the amorphous material specimen. Content values of all minerals except mordenite and clinoptilolite were measured directly by X-ray diffraction method using intensity calibration curves of each standard minerals. The total content values of these minerals were subtracted from 100 to provide the combined content values of mordenite, clinoptilolite and amorphous material.

Table 1. Chemical analyses of several standard samples.

\begin{tabular}{|crrrrrr|}
\hline & Mor. & Clino. & Mica & Mont. & FELD. & \multicolumn{1}{c}{ AM. } \\
\hline $\mathrm{SiO}_{2}$ & 64.33 & 60.85 & 45.60 & 55.84 & 43.36 & 68.38 \\
$\mathrm{Al}_{2} \mathrm{O}_{3}$ & 13.22 & 13.66 & 38.96 & 23.60 & 36.46 & 14.27 \\
$\mathrm{IiO}_{2}$ & 0.22 & 0.33 & 0.13 & 0.12 & $\mathrm{TR}$ & 0.10 \\
$\mathrm{Fe}_{2} \mathrm{O}_{3}$ & 2.29 & 0.82 & 0.81 & 1.62 & 0.58 & 1.17 \\
$\mathrm{CaO}$ & 2.78 & 1.87 & 0.16 & 0.49 & 17.34 & 0.61 \\
$\mathrm{MgO}_{\mathrm{O} O}$ & 0.47 & 1.02 & 0.66 & 2.88 & 0.32 & 0.33 \\
$\mathrm{Na}_{2} \mathrm{O}$ & 2.23 & 2.56 & 0.24 & 2.56 & 0.81 & 2.70 \\
$\mathrm{~K}_{2} \mathrm{O}$ & 1.44 & 3.61 & 8.31 & 0.27 & 0.30 & 4.58 \\
$\mathrm{Ig} . \mathrm{losS}$ & 13.42 & 14.86 & 5.66 & 12.10 & 1.06 & 7.78 \\
$\mathrm{Total}$ & 100.32 & 99.59 & 100.53 & 99.48 & 100.23 & 99.92 \\
\hline
\end{tabular}

Mor.; Mordenite-tuff (B-1D2) from Itado, Clino.; Clinoptilolite-tuff (East Gate P-3) from East Gate, Mica; Sericite from Toei-cho, Mont,; KunIPIA-F, hIGHLY PURIFIED SODIUM MONTMORILLONITE, FELD.; FELdSPAR PREPARED BY MAGNETIC SEPARATION METHOD FROM BASALT, AM.; AMORPHOUS MATERIAL SPECIMEN, SHiRAsU from Futatsui.

Table 2. Mineral composition of standard zeolite specimens and amorphous material [specimen (wt. \%).

\begin{tabular}{|c|rrrrrc|}
\hline & Mor. & Clino, $\alpha-Q$ & Feld. Mont. & Am. & Total \\
\hline $\begin{array}{c}\text { Mordenite-tufF } \\
\text { Itado B-102 } \\
\text { Clinoptilolite-tufF } \\
\text { East Gate P-3 } \\
\begin{array}{c}\text { Shirasu } \\
\text { Futatsui }\end{array}\end{array}$ & 82.0 & 0.8 & & 17.2 & 100 \\
\hline
\end{tabular}

Mor.: Mordenite, Clino.: Clinoptillolite, $\alpha-\theta: \alpha$-Quartz, Feld.: Feldspar Mont.: Montmorillonite, Am.: Mmorphous material. 
(1) Mordenite-tuff (B-102) from Itado, Akita Pref. was used as the mordenite standard.

(2) Clinoptilolite-tuff (East Gate P-3) from East Gate, Nevada, U.S.A. was used as the clinoptilolite standard.

(3) Silicic anhydride, precipitated reagent, from Koso Chemical Co., Ltd. was used as the standard $a$-quartz.

(4) The standard feldspar was prepared by magnetic separation method from basalt which occures in Mitaki, Sendai, Japan (Abe, Aoki and Funayama, 1976). The chemical analysis (Table 1) indicates that purified feldspar mainly consists of anorthite.

(5) Kunipia-F, highly purified sodium montmorillonite, from Kunimine Kogyo Co., Ltd. was used as the standard montmorillonite. To avoid orientation of crystal, the standard montmorillonite was prepared by spray drying in hot air at $400^{\circ} \mathrm{C}$.

(6) Sericite from Toei-cho, Aichi Pref., Japan, was used as the standard mica.

(7) Calcium carbonate, guaranteed precipitated reagent from Nakarai Chemicals, Ltd. was used as the standard calcite.

(8) Imported Georgia kaolinite from U.S.A. was used as the standard kaolinite. Its dehydration loss by T.G. analysis is 13.01 wt. percent.

(9) Under 400 mesh of Shirasu, mainly composed of volcanic glass, from Futatsui, Akita Pref., Japan, was used as the standard amorphous material.

\section{Procedure of measurements and calculation}

The analytical procedures of the sedimentary zeolite rocks were carryed out in the following sequence.

(1) All samples were ground in an agate motar to pass a 200 mesh sieve. An $\mathrm{X}$-ray powder pack was prepared using an aluminum holder. The powderpack sample
Table 3. Analytical conditions of X-ray diffraction method.

\begin{tabular}{|c|c|}
\hline TARGet & $\mathrm{CU}$ \\
FILTER & $\mathrm{NI}$ \\
VOLTAGE & $30 \mathrm{KV}$ \\
CURRENT & $15 \mathrm{MA}$ \\
SLIT & $1^{\circ}-0.3 \mathrm{MM}-1^{\circ}$ \\
SCANNING SPEED & $1^{\circ} / \mathrm{MIN}$. \\
CHART SPEED & $1 \mathrm{CM} / \mathrm{MIN}$. \\
\hline
\end{tabular}

was exposed to nickel-filtered copper radiation from $65^{\circ}$ to $3^{\circ} 2 \theta$ using Rigaku X-ray diffraction unit. Analytical conditions of $\mathrm{X}$-ray diffraction method are shown in Table 3.

(2) Quantitative analysis of amorphous material content was carryed out by the X-ray background method.

(3) Content values of kaolinite and calcite were determined by comparing the peak intensities of specimens with those of the standard samples.

(4) With regard to mordenite, clinoptilolite, $\alpha$-cristobalite, $\alpha$-quartz, feldspar and mica, obtained by the standard binary mixtures method, their mutual mineral composition was calculated in pro ratio.

(5) The percentage values of amorphous material, kaolinite and calcite, measured in (2) and (3) procedures, were subtracted from 100 and then the rest values were divided proportionally to get percentage values of the six common minerals obtained in (4) procedure.

(6) Finally the content of montmorillonite was calculated by substituting the content values of $\alpha$-cristobalite and feldspar for an experimental equation (4). Then the content values of montmorillonite was treated in the same way like procedure (5). Newly obtained content values of $a$ cristobalite and feldspar were substituted again for the equation (4) to get the constant 
value of montmorillonite. If the content of montmorillonite becomes constant, the final mineral composition is known.

$X$-ray diffraction division method

In this experiment, three different techniques were adapted to analyze the mineral composition of sedimentary zeoliterocks by the X-ray diffraction method. Content values of mordenite, clinoptilolite, $\alpha$-quartz, $\alpha$-cristobalite, feldspar and mica were obtained by the so-called standard binary mixtures method. Content values of kaolinite, calcite and montmorillonite were estimated directly comparing the X-ray intensity of specimen with that of standard mineral, although it is desirable to use the standard binary mixtures method. Content value of amorphous material was analyzed independently by the background intensity method. We named collectively the above three X-ray diffraction method and the calculation procedure as "the X-ray diffraction division method". Each different X-ray diffaction method will be discussed in the following chapters in detail.

\section{Quantitative analysis of amorphous material}

The X-ray diffraction patterns of the amorphous material specimens, which are actually accompanied by natural zeolites, are shown in Fig. 1. Their diffuse rings show broad peaks between $22^{\circ}$ and $26^{\circ} 2 \theta$ and they are different from those of synthetic gels. The specimen Ōmori $\mathrm{W}-26$ is accompanied by mordenite and specimen Futatsui Shirasu by clinoptilolite. The specimen Tuff A from Shoshone, California, U.S. A., was used as raw material to synthesize clinoptilolite (Hawkins, Sheppard and Gude, 1976). All of the three specimens contain a small amount of montmorillonite, $\alpha$-quartz and feldspar as crystalline minerals. Chemical analyses of natural and synthetic amor-

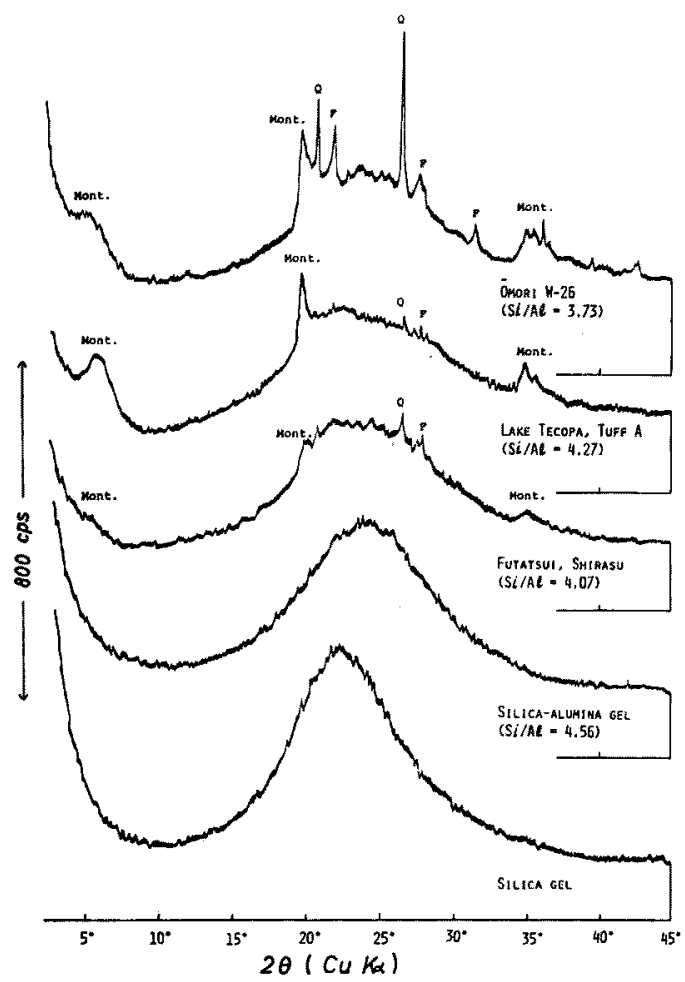

Fig. 1 X-ray diffraction patterns for several natural and synthetic amorphous material specimens.

F: Feldspar, Q: $a$-Quartz, Mont.: Montmorillonite.

phous material specimens are presented in Table 4. It is assumed that the chemical composition of the amorphous material in the zeolite-rocks are similar to those of mother rocks. Analyzed average value of silicon to aluminium for 44 specimens of mordenite-clinoptilolite-rocks, which occur in Japan and U.S.A., is 4.17 and $\mathrm{Si} / \mathrm{Al}$ values for three natural amorphous material specimens are similar.

From the viewpoint of X-ray diffraction patterns and chemical analyses, it is obviously suitable to use a natural amorphous material specimen as the standard sample rather than the synthetic sillicaalumina gel. As a result of X-ray diffrac- 
Table 4. Chemical analyses of natural and synthetic amorphous material specimens.

\begin{tabular}{|c|c|c|c|c|c|c|}
\hline & $\begin{array}{l}\text { SHIRASU } \\
\text { FUTATSUI } \\
\end{array}$ & $\begin{array}{l}\text { OMORI } \\
\text { H-26 }\end{array}$ & $\begin{array}{c}\text { Tuff A } \\
\text { SHOSHONE }\end{array}$ & $\begin{array}{l}\text { SHIRASÜ } \\
\text { KYUSHYU }\end{array}$ & $\begin{array}{l}\text { SILICA } \\
\text { ALUMINA } \\
\text { GEL }\end{array}$ & $\begin{array}{l}\text { SILICA } \\
\text { GEL }\end{array}$ \\
\hline $\mathrm{S}_{1} \mathrm{O}_{2}$ & 68.38 & 64.78 & 67.24 & 72.40 & 62.30 & 79.44 \\
\hline $\mathrm{AL}_{2} \mathrm{O}_{3}$ & 14.24 & 14.73 & 13.37 & 13.63 & 11.59 & \\
\hline $\mathrm{T}_{1} \mathrm{O}_{2}$ & 0.10 & 0.16 & 0.14 & & 0.02 & \\
\hline $\mathrm{Fe}_{2} \mathrm{O}_{3}$ & 1.17 & 2.23 & 1.07 & 2.21 & 0.17 & \\
\hline $\mathrm{CAO}_{\mathrm{O}}$ & 0.61 & 1.01 & 0.78 & 1.51 & 0.01 & \\
\hline $\mathrm{MGO}$ & 0.33 & 0.50 & 1.23 & 0.70 & Non & \\
\hline $\mathrm{NA}_{2} \mathrm{O}$ & 2.70 & 0.94 & 4.04 & 3.86 & 0.20 & 1.05 \\
\hline $\mathrm{K}_{2} \mathrm{O}$ & 4.58 & 2.41 & 4.94 & 2.81 & 0.18 & \\
\hline IG. Loss & 7.78 & 12.81 & 6.97 & 2.83 & 25,13 & 29.51 \\
\hline TOTAL & 99.92 & 99.67 & 99.78 & 99.96 & 99.60 & 100.00 \\
\hline $\mathrm{AL} / \mathrm{S}_{\mathrm{I}}$ & 4.06 & 3.73 & 4.72 & 4.51 & 4.56 & \\
\hline
\end{tabular}
*Average value 859 Shirasu specimens from South Kyushyu area by Shimada
and Fukushige (1955), * abe and Toril (1975).

tion data, Futatsui Shirasu was used as the standard amorphous material in this study on the assumption that the content of amorphous material is $93.8 \mathrm{wt}$. percent.

The X-ray diffraction intensity of halo pattern for amorphous material is generally given as a function of the scattering parameter $S=4 \pi \lambda^{-1} \sin \theta$,

$$
I=I_{0}\left(\sum_{i} f_{i}^{2}+\sum_{i} \sum_{j} f_{i} f_{j} \frac{\sin S \cdot r_{i j}}{S \cdot r_{i j}}\right)
$$

where $\lambda$ is the wave length, $2 \theta$ is the scattering angle, $f_{i}$ is atomic scattering factor of atom $i, r_{i j}$ is a distance from atom $i$ to $j$ and $I_{0}$ is constant. It is apparent that the amplitude and intensity of diffusion ring is decided by the composition and structure of the specimen from equation (1). Therefore, if zeolite-rccks contain only the same kind of amorphous material, we expected to determine the content of amorphous material in the sedimentary zeolite-rocks by the diffraction method.

However, when the specimen contains more than a small proportion of iron, the use of $\mathrm{Cu}-\mathrm{K} \alpha$ radiation in diffraction work results in the excitation of fluorescent radiation from iron. Consequently the back- ground intensity of X-ray diffraction is affected by both the amorphous material and the coexistence iron. On the other hand, Abe and Torii (1975) reported that the intensity of $\mathrm{Fe}-\mathrm{K} \alpha$ increases as increasing the diffraction angle $2 \theta$ from $10^{\circ}$ to about $40^{\circ}$, and that it is relatively constant above $40^{\circ} 2 \theta$. Thus amorphous material and iron in the specimen show different effects on a distribution of background intensity, so it is anticipated to be able to determine the content of amorphous material from two background intensities when $2 \theta$ is different.

In the case of analyzing the quantitative content of amorphous material in the zeolite-rocks, it is desirable that there should not be any crystal peaks in the vicinity of the main peak of diffraction ring of amorphous material. Fortunately, as stated above, the main peak of diffraction ring of actual amorphous material in the zeoliterocks is relatively broad and, as shown in Fig. 2, there is no strong peaks around $24^{\circ}$ $2 \theta$ in either the mordenite or the clinoptilolite. Not only mordenite and clinoptilolite but also feldspar, $\alpha$-quartz, $\alpha$-cristobalite, mica, montmorillonite, $\mathrm{k}$ aolinite and calcite, which are sometimes associated with mord- 


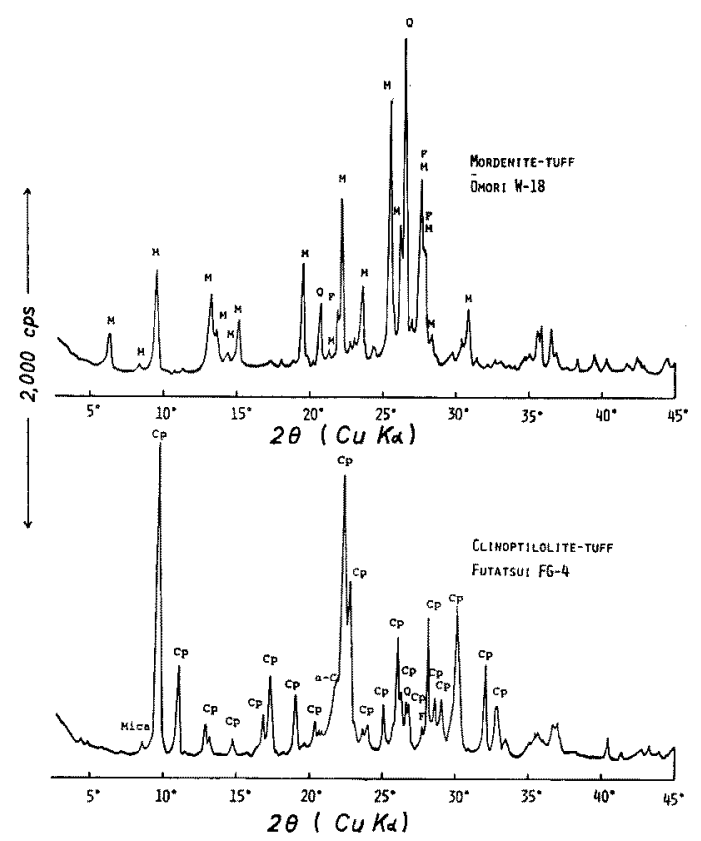

Fig. 2 X-ray diffraction patterns for mordenitetuff and clinoptilolite-tuff.

M: Mordenite, Cp: Clinoptilolite, Q: $\alpha$ Quartz, F: Feldspar, $a$-C: $a$-Cristobalite.

enite and clinoptilolite in the sedimentary rocks, do not have strong crystal peaks between $24^{\circ}$ and $25^{\circ} 2 \theta$. All minerals except mordenite and feldspar, also do not show very weak peaks at near $24.5^{\circ} 2 \theta$, consequently it is observed on the diffraction patterns that there are background between $24.0^{\circ}$ and $24.3^{\circ} 2 \theta$ for mordeniterocks, and between $24.1^{\circ}$ and $24.6^{\circ} 2 \theta$ for clinoptilolite-rocks respectively.

Effects of the amounts of amorphous material and ferric oxide on the background intensities of $2 \theta=24.3^{\circ}$ and $44^{\circ}$ are shown in Fig. 3 and Fig. 4. Experimental specimens were prepared by mixing the standard amorphous material specimen, the standard crystal specimen and ferric oxide reagent at the proper rates. The standard crystal specimen was obtained by mixing $\alpha$-quartz with $a$-alumina completely to get a Si/Al

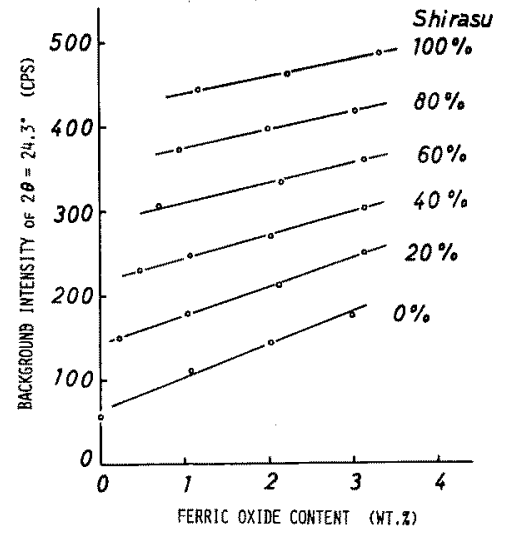

Fig. 3 Effects of amounts of amorphous material and ferric oxide on the background intensity of $2 \theta=24.3^{\circ}$.

$\mathrm{Cu}(\mathrm{Ni}): 30 \mathrm{kv}-15 \mathrm{~mA}$, slit: $1^{\circ}-0,3 \mathrm{~mm}-1^{\circ}$.

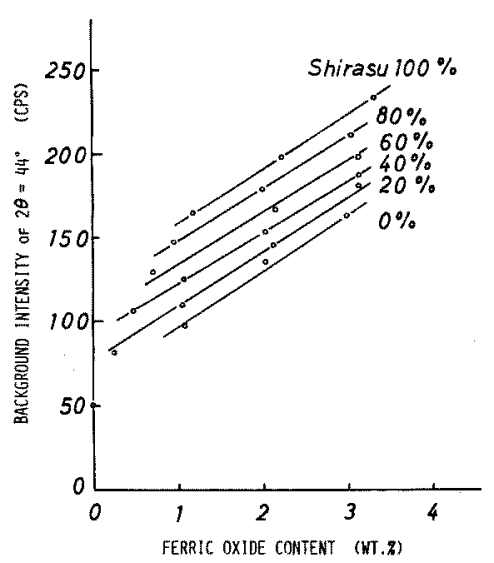

Fig. 4 Effects of amounts of amorphous material and ferric oxide on the background intensity of $2 \theta=44^{\circ}$.

$\mathrm{Cu}$ (Ni): $30 \mathrm{Kv}-15 \mathrm{~mA}$, slit: $1^{\circ}-0.3 \mathrm{~mm}-1^{\circ}$.

value of 4.25 in order to give the near chemical composition like those of zeoliterocks. This may contribute to matrix effects being constant.

As shown in Fig. 3 and Fig. 4, although the background intensities of $2 \theta=24.3^{\circ}$ and $44^{\circ}$ are both affected by the contents of amorphous material and ferric oxide, the 
former is mainly proportional to the amorphous material wt. percent. The latter is more influenced by the ferric oxide wt. percent than the amorphous material wt. percent. Thus it is found that the content of amorphous material is directly proportional to the both background intensities of $2 \theta=24.3^{\circ}$ and $44^{\circ}$. Its near linear relationship can be expressed with the regression equation (2).

$$
X_{a m}=a \cdot I_{243}+b \cdot I_{44}+c
$$

where $X_{a m}$ is wt. percent value of amorphous material, $I_{\mathbf{2 4 3}}$ is the background intensity of $2 \theta=24.3^{\circ}, I_{44}$ is the background intensity of $2 \theta=44^{\circ}$ and $\mathrm{a}, \mathrm{b}$ and $\mathrm{c}$ are constants. The values of constants obtained from the data in Fig. 3 and Fig. 4 are as follows:

$$
a=0.3545, b=-0.3256, c=-8.1535 \text {. }
$$

As mentioned above, the angle $24.3^{\circ} 2 \theta$ was selected because of little or no weak diffraction peaks occuring in this part of the patterns for zeolite-rocks and because this angle is a portion of the diffraction trace that exhibits a high background intensity when appreciable amorphous material is present. Furthermore, background intensity is nearly constant for a few degrees on either side of this value, therefore slightly different reads of angle $2 \theta$ should not materially affect the results.

Analysis of mordenite, clinoptilolite, $\alpha$ quartz, $\alpha$-cristobalite, feldspar and mica by means of standard binary mixtures method.

It was shown by Brindley (1961) that the X-ray intensity ratio $I_{p} / I_{q}$ is directly proporitional to the weight ratio $w_{p} / w_{q}$ for two component $P$ and $Q$ in a multicomponent mixture by the equation (3)

$$
\frac{I_{p}}{I_{q}}=K \cdot \frac{w_{q}}{w_{p}}
$$

where $K$ is a constant. A calibration of
$I_{p} / I_{q}$ against $w_{p} / w_{q}$ for standard mixtures made with pure $P$ and pure $Q$, enables the ratio of $P$ to $Q$ in unknown mixtures to be determined. If the process is applied to all components in pairs, then the composition of the mixture can be found. If amorphous material is present, then the method is no longer usable, however in this study the content of amorphous material was obtained by the background method independently.

The combinations of minerals for the binary mixtures used in this experiment will be explained in the following composition in detail and shown in Table 5 .

(1) In case of mordenite only being contained in the sample of zeolite.

Calibration curves for each binary mixtures of mordenite and associated minerals were obtained using X-ray reflection peaks of mordenite (202), $\alpha$-quartz (101),

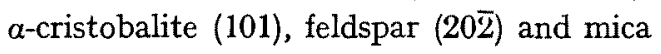
$(001)$. The peak of feldspar $(20 \bar{z})$ is overlapped by a mordenite peak (511) and the peak of mica $(001)$ by a mordenite peak $(020)$, therefore their calibration curves can not be drawn at the origin of the coodinate axes as shown in Fig. 5.

If a large amount of mica is contained in the specimens, the content of $\alpha$-quartz was obtained from a calibration curve, in which the $\mathrm{X}$-ray reflection peaks of mordenite (330) and $\alpha$-quartz(100) are used, because the peak of $\alpha$-quartz (101) may be overlapped by the peaks of mica $(022,003)$. (2) In case of clinoptilolite only being contained in the sample of zeolite.

The mineralogical compositions were calculated from calibration curves for each pairs of clinoptilolite and associated minerals using X-ray reflection peaks of clinoptilolite (132), $\alpha$-cristobalite (101), $\alpha$-quartz (101), feldspar (202) and mica (001). When 
Table 5. The assorted $\mathrm{X}$-ray reflection peaks of minerals in pairs.

\begin{tabular}{|c|c|c|c|c|c|}
\hline \multirow{2}{*}{\multicolumn{2}{|c|}{$\begin{array}{l}\text { SPECIES } \\
\begin{array}{l}\text { OF IMPURITY } \\
\text { MINERALS ANALYZED }\end{array}\end{array}$}} & \multirow[b]{2}{*}{ MoRdenite } & \multirow[b]{2}{*}{ CLINOPTILOLITE } & \multicolumn{2}{|c|}{ MoRDENITE + ClinOPTILOLITE } \\
\hline & & & & $\frac{\text { MOR. }}{\text { CLINO. }}>\frac{1}{3}$ & $\frac{\text { MoR. }}{\text { CLINO }}<\frac{1}{3}$ \\
\hline \multirow{2}{*}{$\alpha$-GUARTz } & $\begin{array}{l}\text { No EXISTENCE } \\
\text { OF MICA }\end{array}$ & $\begin{array}{l}\alpha-Q(101) \\
\text { Mor, }(202)\end{array}$ & $\begin{array}{cc}\alpha-Q & (101) \\
\text { CLINO. } & (132)\end{array}$ & $\begin{array}{ll}\alpha-\alpha & (101) \\
\text { MoR, } & (202)\end{array}$ & $\begin{array}{ll}\alpha-0 & (101) \\
\text { Clino, } & (035)\end{array}$ \\
\hline & $\begin{array}{l}\text { EXISTENCE } \\
\text { OF MICA }\end{array}$ & $\begin{array}{l}\alpha-Q(100) \\
\text { Mor. }(330)\end{array}$ & $\begin{array}{ll}\alpha-Q & (100) \\
\text { Clino, } & (130)\end{array}$ & $\begin{array}{cc}\alpha-Q & (100) \\
\text { MoR, } & (330)\end{array}$ & $\begin{array}{ll}\alpha-Q & (100) \\
\text { CLINo. } & (130)\end{array}$ \\
\hline \multicolumn{2}{|c|}{$\alpha$-CRISTOBALITE } & $\begin{array}{l}\alpha-c(101) \\
\text { Mor. }(202)\end{array}$ & $\begin{array}{cc}\alpha-C & (101) \\
\text { CLINo, } & (132)\end{array}$ & $\begin{array}{ll}a-c & (101) \\
\text { Mor. } & (292)\end{array}$ & $\begin{array}{ll}d-Q & (101) \\
\text { CLINO. } & (130)\end{array}$ \\
\hline \multicolumn{2}{|c|}{ FELDSPAR } & $\begin{array}{l}\text { FELD, }(20 \overline{2}) \\
\text { Mor, }(202)\end{array}$ & $\begin{aligned} \text { FELD. } & (20 \overline{2}) \\
\text { Clino. } & (132)\end{aligned}$ & \multicolumn{2}{|c|}{$\begin{array}{l}\text { FELD, }(20 \overline{2}) \\
\text { MOR, }(202)\end{array}$} \\
\hline \multicolumn{2}{|c|}{ MicA } & $\begin{array}{r}\text { Mica (001) } \\
\text { Mor. (202) }\end{array}$ & $\begin{array}{rr}\text { Mica } & (001) \\
\text { Clino. } & (132)\end{array}$ & $\begin{array}{cc}\text { MICA } & (001) \\
\text { MOR, } & (202)\end{array}$ & $\begin{array}{rr}\text { MicA } & (001) \\
\text { CLINO. } & (002)\end{array}$ \\
\hline \multicolumn{2}{|c|}{ ZEOLITE } & & & \multicolumn{2}{|c|}{$\begin{array}{l}\text { Mor. }(332) \\
\text { CLINo. (035) }\end{array}$} \\
\hline
\end{tabular}

Mor.: Mordenite, Clino.: Clinoptilolite, $\alpha-Q: \alpha$-Quartz, $\alpha-C: \alpha$-Cristobalite, Feld, : Feldspar,
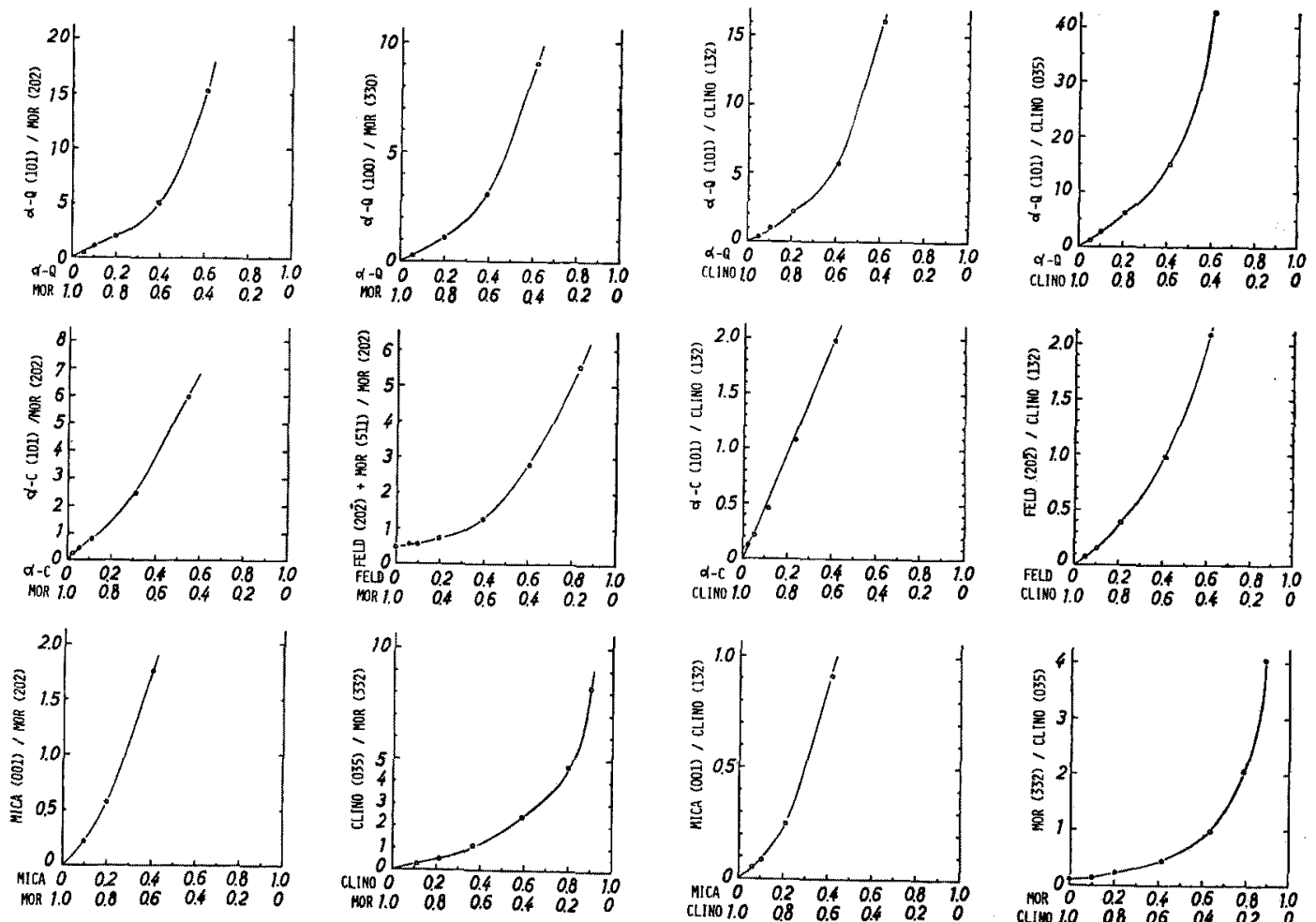

Fig. 5 Calibration curves for binary mixtures of mordenite and assorciated minerals.
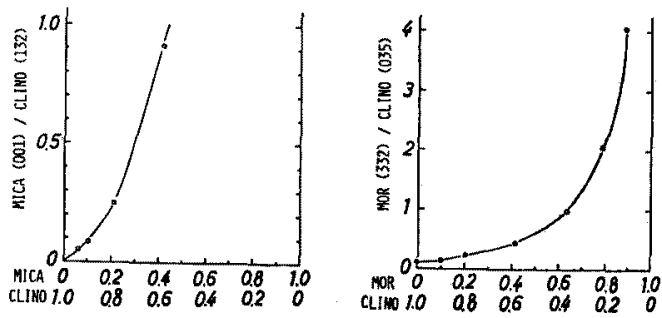

Fig. 6 Calibration curves for binary mixtures of clinoptilolite and assorciated minerals. 
mica is included in the samples, content of $a$-quartz was obtained from a calibration curve in which $\mathrm{X}$-ray reflection peaks of clinoptilolite (130) and $\alpha$-quartz (100) are used. The representative calibration curves for clinoptilolite are shown in Fig. 6.

(3) In case of both mordenite and clinoptilolite being contained in the sample.

As X-ray reflection peak of clinoptilolite (132) is overlapped by that of mordenite (150), the ratio of both zeolite minerals were obtained from a calibration curve using peaks of clinoptilolite (035) and mordenite (332).

When the ratio of mordenite to clinoptilolite is more than about one-third, X-ray reflection peak of mordenite (202) was selected in mineral assorted pairs for calibration curves. This is because the intensity of X-ray reflection peak of clinoptilolite (051) is negligibly weak, even though the peak of mordenite (202) may be overlapped by that of clinoptilolite (051).

When clinoptilolite is associated with a small amount of mordenite in the zeoliterocks (usually the ratio of mordenite to clinoptilolite is less than one-third), the peak of clinoptilolite should be used to get the calibration curves due to the weak intensities of mordenite. However, the main peak of clinoptilolite (132) may be completely overlapped by that of mordenite (150), so other adequate peaks of clinoptilolite should be selected. The selected peaks of clinoptilolite in mineral pairs are shown in Table 5 .

The assorted X-ray reflection peaks of minerals in pairs, which were used for X-ray diffraction method using standard binary mixtures to get mineral compositions in the sedimentary rocks in this study, are in order in Table 5.
Analysis of kaolinite and calcite

Because kaolinite and calcite may be rarely associated with mordenite and clinoptilolite in Japan and their content values assumed to be relatively low even if contained. In this experiment their content values were simply estimated from the intensity ratio of specimen to the standard sample using $\mathrm{X}$-ray reflection peak of kaolinite (001) and that of calcite (104) respectively withcut considering the mass absorption coefficient of the specimens in orde $r$ to simplify the analytical procedures.

\section{Estimation of montmorillonite}

Montmorillonite is frequently associated with both mordenite and clinoptilolite in the sedimentary rocks in Japan but the content of montmorillonite is usually low. There is a special problem involved in the sedimentary zeolite-rocks to estimate the content of montmorillonite by X-ray method, because the $\mathrm{X}$-ray reflection peak of montmorillonite (001) plane may not be detected frequently owing to its low content and degree of its crystalline orientation. Moreover the peaks of (020) plane and (130) plane are completely overlapped by some peaks of the both zeolite minerals and feldsapr.

In this study, the above mentioned strong peaks of montmorillonite can nct be used for the determination of montmorillonite content by X-ray diffraction method, therefore X-ray reflection peak of (060) plane was selected. Because the intensity of (060) peak is originally weak and the content of montmorillonite in the zeoliterocks is usally less than $10 \mathrm{wt}$. percent, the observed peak intensities should be very weak. Moreover (060) peak is overlapped by two weak peaks of feldsapr and $a$ cristobalite, although not overlapped by the 
peaks of mordenite and clinoptilolite. For the above reasons, we assume that it is impossible to use the standard binary mixtures method for estimation of montmorillonite in the sedimentary zeolite-rocks, so in this experiment the montmorillonite mineral content was simply calculated by the following equation (4) which was obtained experimentally.

$$
X_{\text {mont }}=\frac{I_{628}-2.20 \cdot X_{c}-1.84 \cdot X_{f}}{330} \times 100
$$

where $\mathrm{X}_{\text {mont }}, \mathrm{X}_{c}, \mathrm{X}_{f}$; content values (wt. \%) of montmorillonite, $a$-cristobalite and feldspar.

$I_{628} ; \mathrm{X}$-ray intensity of the peak at $62.8^{\circ}$ $2 \theta$.

\section{Estimation of a-quartz and feldspar}

Although the content values of $\alpha$ quartz and feldspar were obtained by the standard binary mixtures method, the direct analysis method was also attempted for a comparison. Calibration curves for the Xray estimation of $\alpha$-quartz and feldsapr were obtained using silica-alumina gel powder as a dilutant. The X-ray intensities of $\alpha$-quartz (100) plane and feldspar (202) plane were measured on a number of standard samples by packing the sample into a holder five times, with the final result as an average of the five readings.

\section{Result and Discussion}

Evaluation of amorphous material content values in the sedimentary rocks by the background method

In this experiment the content of amorphous material in the sedimentary zeoliterocks was obtained by the $\mathrm{X}$-ray background method, however it is very difficult to judge whether content values of amorphous material in the specimens is accurate or not,
Table 6. Mineral composition analyses of two amorphous material specimens (wt. \%).

\begin{tabular}{|cccccc|}
\hline SPECIMEN & AM. & $-Q$ & FELd. & MONT. & TOTAL \\
\hline OMORI W-26 & 83.8 & 1.7 & 2.7 & 14.3 & 102.4 \\
TUFF A & 82.3 & 0.4 & & 14.5 & 97.2 \\
\hline
\end{tabular}

AM.: Amorphous MATERIAL, $\alpha-Q ; \alpha-Q u a r t z$,

Feld.: Feldspar, MONT.: Montmortlllonite.

since it can not be analyzed by any other method. We believe that the obtained content values of amorphous material by means of $\mathrm{X}$-ray background method are extremely accurate on account of the following three reasons.

(1) The content values of amorphous material, $\alpha$-quartz, feldsapr and montmorillonite in two natural amorphous material specimens were separately analyzed by the different $\mathrm{X}$-ray diffraction methods which have been introduced in this paper. As shown in Table 6, total values of mineral compositions in both specimens show around 100 percent and this may suggest that the content values of amorphous material obtained by the background method are fairly exact.

(2) Generally almost all sedimentary

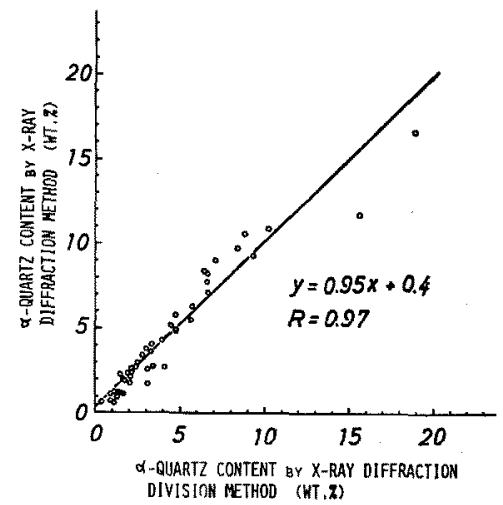

Fig. 7 Relationship between two of $a$-quartz content values by $X$-ray diffraction division method and ordinary X-ray diffraction method. 
zeolite-rocks in Japan contain $\alpha$-quartz. We therefore consider $a$-quartz in the specimens as an indicator, and analyzed the content values of $\alpha$-quart $z$ in the same sample by two different methods for comparison in many specimens. One method was the
X-ray diffraction division method adapted in this experiment to determine the mineral composition of zeolite-rocks and the obtained values of each minerals are taken in consideration of amorphous material values. Also the other content values of $a$-quartz

Table 7. Mineral composition analyses of sedimentary zeolite rocks.

\begin{tabular}{|c|c|c|c|c|c|c|c|c|c|c|c|}
\hline No. & SPECIMENS & Mor. & Clino. & $\alpha-c$ & $\alpha-Q$ & FELD. & Mica & MONT. & $k$ & CAL. & AM. \\
\hline 1 & HABORO & & 57.4 & 5.5 & 1.1 & 9.0 & & 3.5 & & & 23.5 \\
\hline 2 & YOICHI & 9.0 & 60.3 & 5.5 & 0.9 & 3.8 & 6.9 & 1.5 & & & 12.2 \\
\hline 3 & OSHAMANBE A & & 65.1 & 3.8 & & 11.9 & 2.0 & & & & 17,2 \\
\hline 4 & FutATsuI FW-5 & & 73.5 & 4.5 & 0.7 & 3.1 & 1.7 & & & & 16.4 \\
\hline 5 & FUTATSU1 FG-4 & & 72.0 & 3.6 & 1.6 & 4.5 & 5.7 & 1.1 & & & 11.4 \\
\hline 6 & $0 G A$ & 88.0 & & & 0.5 & & & & & & 11.5 \\
\hline 7 & TATEYAMAZAKI B & 8.9 & 58.6 & 1.5 & 4.8 & 2.3 & 8.5 & 6.2 & & & 9.2 \\
\hline 8 & ITADO B-3 & 65.6 & 6.8 & 0.7 & 1.3 & 0.4 & & 1.8 & & & 23.4 \\
\hline 9 & Minase & 61.7 & & 4.4 & 2.9 & 6.6 & & 6.1 & & & 18.2 \\
\hline 10 & SAWAGUCHI & & 59.7 & 9.6 & 2.1 & 15.9 & & & & & 12.7 \\
\hline 11 & ITAYA B & 49.2 & 17,5 & 2.3 & 1.8 & 7,1 & & 4.2 & & & 17.9 \\
\hline 12 & OMORI $W-1$ & 21.5 & & 0.4 & 29.3 & 23.3 & & 4.6 & 1.9 & & 18.5 \\
\hline 13 & OMORI W-14 & 66.8 & & $\eta .5$ & 8.4 & 7.8 & & 6.8 & & & 17.0 \\
\hline 14 & OMORI H-18 & 53.8 & & 0.2 & 6.6 & 16.8 & & & & & 23.6 \\
\hline 15 & NARUAI A & 65.0 & 5,6 & 1.0 & 2.4 & 8.5 & & & & & 17.5 \\
\hline 16 & KAWARAGO $S$ & 60.9 & 3.1 & 9.7 & 2.1 & 6.5 & & 5.6 & & & 21.1 \\
\hline 17 & TENEI & 68.1 & & 0.5 & 5.7 & 3.3 & & 3.9 & & & 18.6 \\
\hline 18 & FUKURODA & & 69.7 & 4.4 & 1.1 & 4.5 & 1.8 & 5.5 & & & 13.1 \\
\hline 19 & TAMAYU & 23.0 & 49.6 & 8.6 & 1.1 & & & 3.9 & & & 13.7 \\
\hline 20 & SHIZUMA A & 16.2 & 38.5 & 1.7 & 15.2 & 14.2 & & 1.8 & & & 12.3 \\
\hline 21 & IWAMI & 10.3 & 60.4 & 4.5 & & 2.0 & & 8.9 & & & 14.7 \\
\hline 22 & AMAGOCHI & 58.0 & & 0.5 & 10.2 & 5,9 & & 2.5 & & & 22.9 \\
\hline 23 & ARITA & 45.5 & & 2.8 & 0.8 & 8.3 & & 29.1 & & & 22.4 \\
\hline 24 & Kampo A & 37.6 & & 5.4 & 2.1 & 26.1 & 1.5 & 7,3 & 1.9 & & 18.1 \\
\hline 25 & Whangape Haboun & 50.6 & 3.8 & 0.9 & 4.0 & 5.9 & & 7.5 & & & 28.2 \\
\hline 26 & NoRth CAPE & & 67.2 & 1.0 & 4.1 & 7.1 & & 2.7 & & 6.5 & 11.5 \\
\hline 27 & SOUTH AFRICA & 9.9 & 50.8 & 11.3 & 1.3 & 4.5 & & & & & 22.1 \\
\hline 28 & LOVELOCK & 35.8 & 2.3 & 8.7 & 1.6 & 17.3 & & 15.7 & & 0.7 & 17.9 \\
\hline 29 & JERSEY VALLEY & & 84.5 & 0.4 & & 2.1 & 2.3 & 3.4 & & 3.5 & 3.7 \\
\hline 30 & BEAVER RIM & & 82.3 & 5.2 & & 2.3 & 1.9 & 1.3 & & & 7.9 \\
\hline 31 & IDAHO & & 61.9 & 1.9 & 2.1 & 8.9 & 9.0 & 4.9 & & & 13.3 \\
\hline 32 & ANACONDA $1010 \mathrm{~A}$ & & 90.2 & 1.0 & 9.7 & & 2.6 & & & & 5.5 \\
\hline
\end{tabular}

Mor : Mordenite, Clino: : Clinoptilolite, -C: -Cristobalite, - 9 : -Quartz,

FELD.: FELDSPAR, K: RAOLINITE, CAL.: CALCITE; AM,: AMORPHOUS MATERIAL' 7 THE 32 SAMPLES ANALYZED, CHARACTERIZED BY THEIR NUMBERS IN TABLE 7 AND THEIR LOCATIONS OF OCCURRENCE ARE DESCRIBED AS FOLLOWS. HE COMPANIES, WHICH HAVE THED ZEOLITE-PRODUCTS OR PROVIDE US THE SPECIMENS, ARE INDICATED IN THE PARENTHES. JAPAN; 1 HaBORO, HOKKaIDO, JaPAN; 2 YoICH I, HOKKAIDO, COAPAN; 3 DSHAMANBE HOKKAIDO, JAPAN,

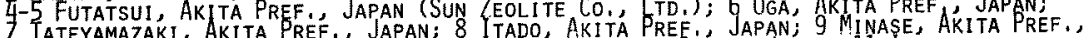

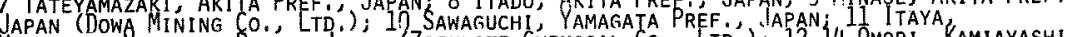

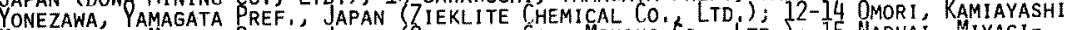

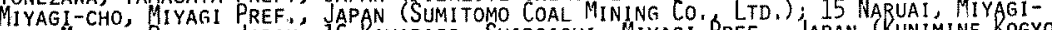
Cho, Miyagi Pref., Japan; 16 Rawarago, Shiroishi, Miyagi Pref. Japan Runimine kogyo CO. LTD.): 17 TENEI, FUKUSHIMA PREF.', IAPAN (FUJI ZEOLITE Co.); 18 FUKURODA, IBARAG

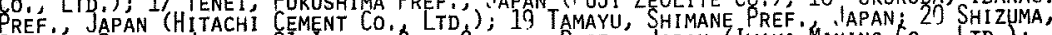

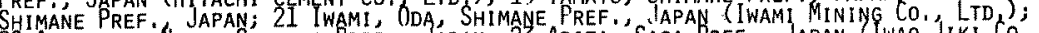
22 Amagochi, "Nima Shimane Pref., Japanj 23 ARITA, Saga Pref, Japan (IWAO Jlki Co.,

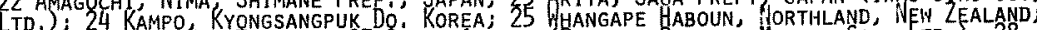
26 NORTH CAPE, NEW ZEALAND 27 SouTH AFRICA (PRATLEY PERLITE, MINING Co,, LTP.) 28

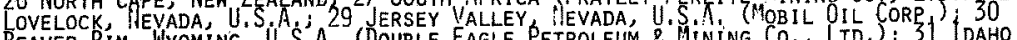

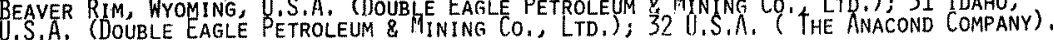


was analyzed directly by the different diffraction method using a calibration curve.

The relationship between the two, of $\alpha$-quartz content values for 46 specimens, which were measured indirectly and directly by the two different X-ray diffraction methods respectively, is shown in Fig. 7. It is evident that both content values of $a$-quartz obtained by the two different methods are extremely similar. This result also shows although indirectly, that the content values of amorphous material analyzed by the background method is considerably accurate.

(3) As described by Torii, Hotta and Asaka (1979), the content values of mordenite and clinoptilolite obtained by the $\mathrm{X}$-ray diffraction division method are closely agreement with those obtained by gas adsorption method and C.E.C. method. This consequence implys that not only the content values of zeolites but also those of amorphous material are reasonable accurate.

The mineral composition of sedimentary zeolite-rocks

The mineral composition of more than 70 specimens of the sedimentary zeoliterocks, which contain mordenite and/or clinoptilolite, were analyzed by the $\mathrm{X}$-ray diffraction division method. Representative data from 32 are indicated in Table 7.

As shown in Table 7, most of all sedimentary mordenite-clinoptilolite-rocks contain $\alpha$-quartz, $\alpha$-cristobalite and feldspar as crystal impurities. It seems that the ratio of $a$-quartz to $a$-crystobalite may be larger, more so when they are associated with mordenite than with clinoptilolite. This result may reflect the difference of formation conditions such as temperature, pressure, etc., between mordenite and clinoptilolite.

About two-thirds of the 70 specimens contain montmorillonite without any connection between mordenite-rocks and clinoptilolite-rocks. Mica seems to be associated with clinoptilolite particularly.

The content values of clinoptilolite in saline-alkaline lake deposits from U.S.A. seem to be larger than those in metamorphism deposits from Japan. However, the content values of mordenite from Japan appear larger than those from the U.S.A., New Zealand end Korea.

\section{AGKNOWLEDGEMENTS}

The authors wish to express their sincere thanks to Dr. T. Sameshima, Dr. R.B. Laudon, Dr. M. Aoki, Mr. W.S. Choi, Mr. D.W. Leonald, Mr. G.M. Prately, Dr. K. Araki, Mr. Y. Endo, Mr. H. Ihara, Mr. T. Inoue, Mr. H. Ishimaru, Mr. M. Kondo, Mr. T. Negishi, Mr. M. Obata, Mr. Y. Ōmori, Mr. Y. Onodera, Mr. R. Oyama, Mr. K. Suga and Mr. M. Taniguchi, for providing specimens in this study. Special thanks are due to Mr. D.W. Leonald for his critical readings of the manuscript of this paper.

\section{REFERENCES}

Abe, T. and Torii, K. (1975), The determination of amorphous silica and $\mathrm{Fe}_{2} \mathrm{O}_{3}$ by X-ray background method. Jour. Clay Sci. Soc. Japan., 14, 109-115. (in Japanese with English abstract).

Abe, T., Aoki, K. and Funayama, Y. (1976), Chemical compositions of Neogene Tertiary volcanic rocks from Sendai area. Jour. Japan. Assoc. Min. Petr. Econ. Geol., 71, 137-146. (in Japanese with English abstract).

Brindley, G.W. (1961), Quantitative analysis of clay mixtures. In G. Brown (Ed.) The X-ray identification and crystal structure of clay minerals. Mineralogical Society, London, 489-516. 
Hawkins, W.D., Sheppard, R.A. and Gude, A.J. (1976). Hydrothermal synthesis of clinoptilolite, Prog. and Abstracts, Zeolite '76Inter. Conf. Occur. Prop. Util. Nat. Zeolites, 32-33. (abstract).

Mumpton, F.A. (1978), Natural zeolites - a new industrial mineral comodity. In L.B. Sand and F.A. Mumpton (Ed.) Natural Zeolites: Occurrence, properties, use. Pergamon Press, Elinsford, N.Y. 3-27.

Nakajima, W. and Tanaka, K. (1967), Zeolite-bearing tuffs from the Izumi Group in the central part of the Izumi Mountain Range, southwest Japan, with reference to mordenite-bearing tuffs and laumontite tuffs. Jour. Geol. Soc. Japan., 73, 237-245. (in Japanese with English abstract).

Negishi, T. (1972), On the measurement of cation exchange capacity of zeolite tuffs. Jour.
Clay Sci. Soc. Japan., 12, 23-30. (in Japanese with English abstract).

Shimada, K. and Fulkushige, Y. (1975), Properties of volcanic glass in Shirasu. Jour. Seramic Soc. Japan., 83, 565-570.

Torii, K. et al. (1975), Estimation of mordenite in tuffs by means of gas adsorption method. Reports Govern. Indust. Res. Inst. Tohoku., 6, 71-73. (in Japanese).

. (1978), Utilization of natural zeolites in Japan. In L.B. Sand and F.A. Mumpton (Ed.) Natural Zeolites: Occurrence, properties, use. Pergamon Press, Elmsford, N.Y. 441-450.

. Hotta, M. and Asaka, M. (1979), Quantitative estimation of mordenite and clinoptilolite in sedimentary rocks (II). Jour. Japan. Assoc. Min. Petr. Econ. Geol. (in press).

\title{
堆積岩中のモルデンフッ石および斜プチロルフッ石の定量 (I)
}

\author{
鳥居 一雄・堀田 正己·浅賀 質

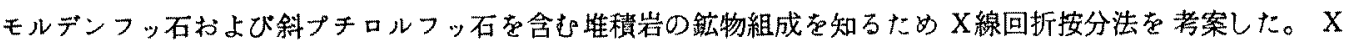 \\ 楾回折安分法は内部標準を使用せず，また加熱あるいは化学処理するととなく，堆積岩中のゼオライトをX線 \\ 粉末回折法でみ定量するととを目的として確立されたもので，異なる三方洗のX線回折法よりなる。モルデ \\ ンフッ石，斜プチロルフッ石，石英，クリストバル石，長石および雲母の量は二成分系検量線法により得られ \\ た。非晶物質量は二点バックグランド法より求められ，またモンモリロナイトは標準試料との強度比より得ら \\ れた。日本，アメリカ合衆国，韓国，ニューシランド，南アフリカ共和国より産する代表的な 32 個の含フッ石 \\ 岩の鉱物組成が表示されている。
}


欧和対盟表

Itado

Koso Chemical Co., Ltd.

Kunimine Kogyo Co., Ltd.

Toei-cho

Sanshin Mining Ind. Co., Ltd.

Nakarai Chemicals, Ltd.

Futatsui

Ōmori, Kamiayashi, Miyagi-cho

Haboro

Tateyamazaki

Minase

Sawaguchi

Itaya, Yonezawa

Zieklite Chemical Co., Ltd.

Sun Zeolite Co., Ltd.

Naruai, Miyagi-cho

Kawarago, Shiroishi

Tenei

Fukuroda

Tamayu

Shizuma

Iwami, Ōda

Amagochi, Nima

Iwao Jiki Co., Ltd.
板戸

小宗化学工業株式会社

クニミネ工業株式会社

東栄町

三信鉱業株式会社

半井化学薬品株式会社

二ツ井

它城町上愛子大森

羽蝶

館山渏

皆瀬

沢口

米沢节板谷

ジークライト化学磪業株式会社

サン・ゼオライト工業株式会社

宮城町鳴合

白石市川原子

天栄

袋田

玉湯

静間

太田市石見

仁摩天河内

岩尾磁器工業株式会社 